\title{
Feast and famine in Antarctica: seasonal physiology in the limpet Nacella concinna
}

\author{
Keiron P. P. Fraser* ${ }^{*}$ Andrew Clarke, Lloyd S. Peck \\ Natural Environment Research Council, Biological Sciences Division, British Antarctic Survey, High Cross, Madingley Road, \\ Cambridge CB3 0ET, United Kingdom
}

\begin{abstract}
The few studies of Antarctic marine invertebrates that have previously examined seasonal changes in physiology have concentrated on species that cease feeding for extended periods in the austral winter. In contrast, the limpet Nacella concinna (Strebel, 1908) feeds throughout the year. To compare the differing physiological responses demonstrated by a continually feeding species and species that cease feeding during winter we measured seasonal changes in $N$. concinna faecal egestion, oxygen consumption, O:N ratios, ammonia, urea and primary amine excretion at 4 points in the year. Tissue ash-free dry mass decreased by $47 \%$ and faecal egestion 10 -fold from summer to winter. Metabolic rates decreased significantly in winter (December, $0.61 \pm 0.04 \mu \mathrm{mol} \mathrm{O}_{2} \mathrm{~h}^{-1}$; October, $0.38 \pm$ $0.04 \mu \mathrm{mol} \mathrm{O} \mathrm{O}^{-1}$ ), but to a much lesser degree than other Antarctic marine invertebrates. Ammonia and urea excretion rates showed significant seasonal variations, while no clear pattern was evident in primary amine excretion. Ammonia excretion decreased during late summer and early winter before increasing in spring (minimum, February, $66.23 \pm 5.72 \mathrm{nmol} \mathrm{h}^{-1}$; maximum, December, 170.83 $\pm 9.50 \mathrm{nmol} \mathrm{h}^{-1}$ ). Urea excretion was low in summer (December, $9.88 \pm 1.60 \mathrm{nmol} \mathrm{h}^{-1}$ ) and maximal (July, $26.70 \pm 4.05 \mathrm{nmol} \mathrm{h}^{-1}$ ) in winter. Urea and primary amine excretion combined accounted for between 10 and $38 \%$ of total nitrogen excretion. O:N ratios ranged between 7 and 20 and demonstrated that although protein was the dominant respiratory substrate throughout the year, in late summer and early winter lipids and carbohydrates were also utilised for metabolism. $N$. concinna has a low degree of metabolic seasonality due to the maintenance of high winter metabolic rates. Although feeding during winter provides some energy, it is insufficient to offset the substantial utilisation of tissue energy stores to balance the metabolic budget.
\end{abstract}

KEY WORDS: Limpet · O:N ratio $\cdot$ Nitrogen excretion $\cdot$ Oxygen consumption $\cdot$ Seasonal metabolism Resale or republication not permitted without written consent of the publisher

\section{INTRODUCTION}

In the tropical marine environment, both temperature and food availability are fairly constant, whereas in temperate waters, food availability and water temperature vary concurrently (Clarke 1988). In contrast, the Antarctic marine environment is characterised by low but very stable temperatures (Littlepage 1965) and a highly seasonal food supply; food availability and temperature are effectively uncoupled (reviewed in Clarke 1988, Clarke et al. 1988, Clarke \& Leakey

*E-mail: kppf@pcmail.nerc-bas.ac.uk
1996). Antarctica therefore offers the opportunity to study the physiological effects of food consumption and temperature independently.

In general, Antarctic marine organisms grow slowly due to the combination of seasonal variability in food availability and rate limitation by temperature (Clarke 1983). Many benthic species cease feeding in winter for periods ranging between a few weeks and many months (Barnes \& Clarke 1994, Brockington 2001a, Brockington \& Peck 2001). In contrast, the limpet Nacella concinna and the bryozoan Arachnopusia inchoata are unusual for Antarctic marine ectotherms because they feed throughout the year at Signy Island in the South Orkney Islands, although feeding rates in N. concinna do de- 
crease significantly during winter (Barnes \& Clarke 1994, A. Clarke \& E. Prothero-Thomas unpubl. data). Recently, published studies have examined seasonal metabolism and ammonia excretion in Sterechinus neumayeri and Laternula elliptica, both species that cease feeding for in excess of 4 mo during winter (Brockington 2001a, Brockington \& Peck 2001). N. concinna provides an interesting opportunity to compare seasonal metabolism and nitrogenous excretion in a species that feeds continually with species that undergo a non-feeding period during winter.

Considerable literature exists on various aspects of Nacella concinna physiology, with previous authors reporting oxygen consumption (Ralph \& Maxwell 1977, Houlihan \& Allan 1982, Peck \& Veal 2001), nitrogen excretion (Clarke et al. 1994), faecal egestion (Clarke 1990), pedal mucus production (Peck et al. 1993) and shell repair (Cadée 1999). Several studies have also examined the general ecology (Walker 1972, Berry \& Rudge 1973, Picken 1980) and reproduction (Picken \& Allan 1983, Stanwell-Smith \& Clarke 1998, Powell et al. 2001) of N. concinna. However, almost all of these studies have been restricted to the austral summer because of the logistical constraints of polar research. No data currently exist on seasonal metabolism and nitrogen excretion in $N$. concinna or any Antarctic gastropod. Measurements during the austral summer have suggested that urea and primary amines do not comprise a large proportion of nitrogen excretion in $N$. concinna and Laternula elliptica, although seasonal changes in excretion have not been examined (Clarke et al. 1994, Brockington 2001a, Brockington \& Peck 2001).

The current work is part of a much larger study testing the hypothesis that the highly seasonal Antarctic environment will result in seasonal changes in physiology, protein synthesis, RNA dynamics and tissue proximate composition of Nacella concinna. This part of the study was designed to answer the following questions: (1) Does $N$. concinna metabolism and feeding rate vary seasonally? (2) How does nitrogenous excretion change throughout the year, and do the relative and absolute amounts of ammonia, urea and primary amine change? (3) What respiratory substrates are used to fuel metabolism in $N$. concinna and do they change seasonally?

\section{MATERIALS AND METHODS}

Sampling. Experimental work was carried out at Rothera Research Station (67³4' 07" S, 68 07' 30" W), Adelaide Island, Antarctic Peninsula, between February and December 1999. Nacella concinna were collected in February, July, October and December by
SCUBA divers from South Cove, Rothera Point, at depths between 6 and $15 \mathrm{~m}$ (for site location see Brockington \& Peck 2001). Immediately after collection, limpets were returned to the laboratory and placed in a through-flow aquarium under a simulated local light:dark cycle. Predicted sunrise and sunset times (POLTIPS 3, Proudman Oceanographic Laboratory) were used in conjunction with a mechanical timer to control the lighting regime. Aquarium daily mean water temperatures varied between 0.48 and $0.68^{\circ} \mathrm{C}$ in February, -1.31 and $-1.40^{\circ} \mathrm{C}$ in July, -1.03 and $-1.07^{\circ} \mathrm{C}$ in October, and -0.28 and $-0.43^{\circ} \mathrm{C}$ in December. $N$. concinna were maintained in the aquarium for a maximum of $48 \mathrm{~h}$ prior to use in experiments. Collected limpets were not specifically fed but were observed grazing biofilms on the sides of the tank.

Measurement of oxygen consumption and nitrogen excretion. Oxygen consumption rates were measured using closed-bottle techniques. Preliminary work established the respirometer size and incubation time required to measure respiration rates in a range of limpet sizes. Preliminary trials demonstrated that respiration rates were independent of water oxygen content down to oxygen levels that were $80 \%$ of control chambers containing no limpets.

Nacella concinna were placed in either 80 or $180 \mathrm{ml}$ Perspex respirometers, depending on size, for periods ranging between 6 and $9 \mathrm{~h}$, resulting in oxygen concentrations decreasing to 85 to $90 \%$ of control chambers. At each seasonal sampling point, both oxygen consumption and nitrogen excretion were measured in 20 or 21 separate individuals. Respirometers were maintained at stable temperatures by placement in flowing seawater at ambient temperatures during respirometry measurements. At the end of the measurement period, oxygen concentrations in the respirometers were measured using couloximetric techniques (Peck \& Uglow 1990, Peck \& Whitehouse 1992). At the same time, water samples were collected for measurement of ammonia, urea and primary amines. All rates were corrected for control values (experimental chambers containing no limpets and run in parallel), by subtracting the control respiration or excretion rate from the experimental respiration or excretion rates. Water samples for ammonia measurement were acidified with $1.0 \mathrm{M} \mathrm{HCl}(\mathrm{pH}<4.0)$ and frozen. Samples collected for the measurement of urea and primary amines were frozen without acidification. Frozen acidified ammonia standard samples do not leach ammonia (Degobbis 1973, K. Fraser unpubl. data), and urea and primary amine samples are also stable when frozen (Price \& Harrison 1987, Clements \& Hilbish 1991). The dry tissue mass of limpets used for respirometry measurements was measured after shucking and drying to constant mass at $60^{\circ} \mathrm{C}$ before ash 
masses were obtained by incineration at $465^{\circ} \mathrm{C}$ for $24 \mathrm{~h}$. Ash-free dry masses (AFDM) were calculated by subtracting ash mass from dry mass.

Analysis of ammonia, urea and fluorescaminepositive substances. All glassware for nitrogen analysis was acid-washed prior to use. Ammonia was assayed using the phenol-hypochlorite method of Solorzano (1969) as modified by Liddicoat et al. (1975), Catalano (1987) and Clarke et al. (1994). The only modification to the methodology described in Clarke et al. (1994) was that the pH of ammonia samples was adjusted back to 7.0 prior to assaying. Urea was assayed using the diacetylmonoxime method of Rahmatullah \& Boyde (1980) with the following modifications: (1) as concentrations in seawater were measured in the present work, rather than urea concentrations in biological material, samples were not deproteinised; and (2) $0.5 \mathrm{ml}$ colour reagent was added to $1 \mathrm{ml}$ water samples.

Primary amines were measured flourometrically (excitation wavelength $390 \mathrm{~nm}$, emission wavelength $480 \mathrm{~nm}$ ) after reaction with fluorescamine (North 1975, Clements \& Hilbish 1991). Sample concentrations were determined by comparison to known glycine (Sigma) standards and are expressed as fluorescamine-positive substances (FPS).

All nitrogen excretion rates were expressed as nmol nitrogen $\mathrm{h}^{-1}$ (1 mol urea contains $2 \mathrm{~mol}$ nitrogen). O:N ratios were calculated on an atomic basis and only included ammonia nitrogen. FPS and urea nitrogen are unlikely to be derived from protein deamination (see 'Discussion').

Faecal egestion measurements. The methods used to measure faecal egestion rates in Nacella concinna have previously been described (Clarke 1990). Previous work has shown that faecal egestion does not decline for the first $3 \mathrm{~d}$ after sampling when limpets are held in non-feeding conditions, although it does decline sharply thereafter (Clarke 1990). Immediately after the limpets were collected, approximately 100 were divided into 6 groups and placed in 51 glass beakers containing 41 of seawater. The number of limpets in each beaker depended on limpet size and varied between 10 and 30 individuals. To prevent contamination, beakers were covered with aluminium foil, and to maintain stable water temperatures, partly submerged in flowing seawater at ambient temperatures. At intervals of $12 \mathrm{~h}$, faeces were gently removed using a pipette, washed in distilled water and checked for contaminating shell fragments using a microscope. Faeces were then transferred to a pre-weighed crucible and dry and ash mass measured as previously described. The seawater in the beakers containing the limpets was changed after faeces were removed. Faeces were collected over a $48 \mathrm{~h}$ period at which point limpet length, width and mass were measured. Limpets were shucked and flesh dry and ash masses measured as previously described.

Statistical analysis. All data are expressed as mean \pm SEM (standard error of the mean). Statistical analysis was carried out using Minitab version 13.31 (Minitab). Data were tested for normality prior to statistical testing using the Anderson-Darling test (Sokal \& Rohlf 1995). If data were normally distributed, they were analysed using ANOVA; if they were not, the nonparametric Kruskal-Wallis test was used.

\section{RESULTS}

\section{Oxygen consumption and nitrogen excretion}

Although there was no significant difference in limpet shell lengths between seasonal samples, body masses were significantly different (Table 1). The AFDM of limpets in February were also significantly higher (Kruskal-Wallis, $\mathrm{p}<0.05, H=19.10$, df $=3$ ) than in October or December (Fig. 1). Correcting physiolog-

Table 1. Nacella concinna. Seasonal variation in tissue mass and shell length of the Antarctic limpet at Rothera Point. All data are mean \pm SEM $; n=20$ (July, October), $n=21$ (February, December), oxygen consumption and nitrogen excretion limpets; $\mathrm{n}=104$ (July, December), $\mathrm{n}=105$ (February), $\mathrm{n}=110$ (October), faecal egestion limpets

\begin{tabular}{|c|c|c|c|c|}
\hline & \multicolumn{2}{|c|}{ Oxygen consumption and nitrogen excretion limpets } & \multicolumn{2}{|c|}{ Faecal egestion limpets } \\
\hline & Shell length (mm) & Mass $(g)$ & Shell length (mm) & Mass (g) \\
\hline Feb & $25.79 \pm 0.73$ & $2.06 \pm 0.20^{\mathrm{a}}$ & $21.73 \pm 0.41$ & $1.30 \pm 0.08$ \\
\hline Jul & $24.22 \pm 0.26$ & $1.62 \pm 0.06$ & $22.23 \pm 0.60$ & $1.53 \pm 0.12$ \\
\hline Oct & $23.54 \pm 0.76$ & $1.23 \pm 0.14^{\mathrm{a}}$ & $21.88 \pm 0.63$ & $1.33 \pm 0.13$ \\
\hline Dec & $23.8 \pm 0.75$ & $1.57 \pm 0.14$ & $23.06 \pm 0.63$ & $1.57 \pm 0.14$ \\
\hline Kruskal-Wallis $H$ & 5.58 & 12.5 & 2.94 & 5.87 \\
\hline df & 3 & 3 & 3 & 3 \\
\hline $\mathrm{p}$ & 0.134 & $<0.05$ & 0.401 & 0.118 \\
\hline
\end{tabular}




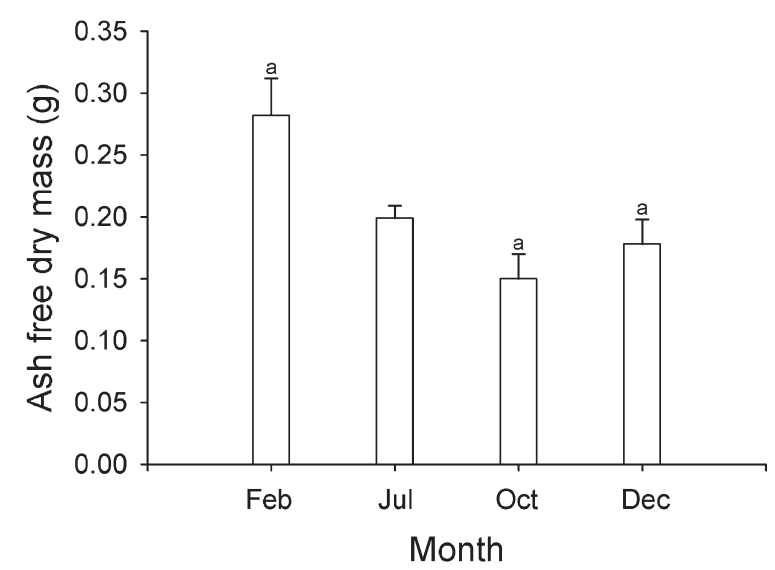

Fig. 1. Nacella concinna tissue ash-free dry mass. Data are mean values for limpets of shell length $24.31 \pm 0.35 \mathrm{~mm}$. Shell lengths did not vary between samples ( $p>0.05)$ and therefore, tissue mass was not corrected for scaling effects of shell size variation. All bars are mean \pm SEM, bars with the same letter are significantly different to each other (Kruskal-Wallis test, $\mathrm{p}<0.05)$, February and December $\mathrm{n}=21$, July and October $\mathrm{n}=20$

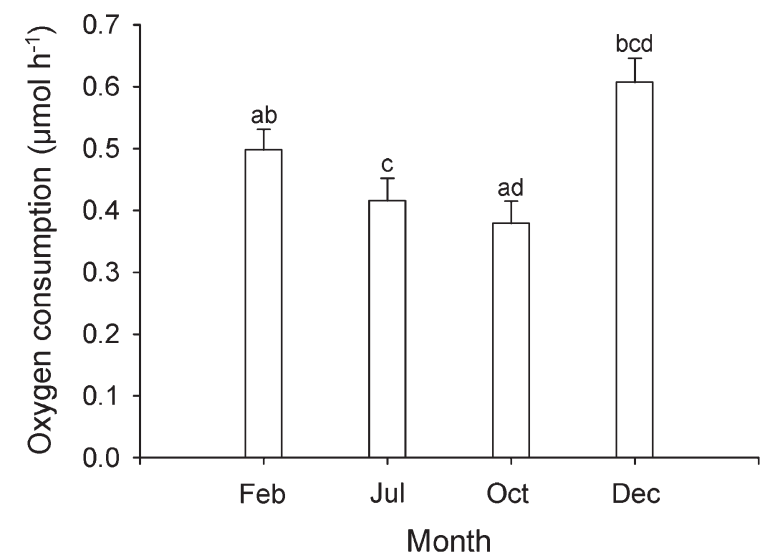

Fig. 2. Nacella concinna. Seasonal variation in oxygen consumption at Rothera Point, Antarctica. All data expressed as $\mu \mathrm{mol} \mathrm{O}_{2}$ ind. $^{-1} \mathrm{~h}^{-1}$ and standardised to a limpet of tissue dry mass $247 \mathrm{mg}$ using a scaling exponent of 0.82. All bars are mean \pm SEM, bars with the same letter are significantly different to each other (ANOVA, $p<0.05$ ), February and December $n=21$, July and October $n=20$

ical data for variations in size is problematic when both tissue mass and mass-specific rates are changing. Correcting to a standard shell length will emphasise changes in tissue mass and per individual physiological rates, while correcting to a standard tissue mass highlights variation in mass-specific physiological rates. Due to the significant differences in body mass, oxygen consumption, ammonia, urea and FPS excretion were standardised to a $247 \mathrm{mg}$ dry mass ind. (the mean mass of animal used) using a scaling coefficient of 0.82 for oxygen consumption and nitrogen excretion (Clarke et al. 1994).

Oxygen consumption rates were significantly lower during the winter (ANOVA, $\mathrm{p}<0.05, F=7.45, \mathrm{df}=3$ ), with winter rates about $2 / 3$ of maximum summer values. The lowest oxygen consumption rates were measured in October $\left(0.38 \pm 0.04 \mu \mathrm{mol} \mathrm{h}^{-1}\right)$ and the highest in December $\left(0.61 \pm 0.04 \mu \mathrm{mol} \mathrm{h}^{-1}\right.$; Fig. 2). The decline in oxygen consumption from the end of summer and into the winter was followed by a rapid increase at the start of the summer. Because these data have been corrected to a standard tissue mass, these changes reflect variation in mass-specific metabolism (metabolic rate per unit tissue mass), not changes in tissue mass per se.

Nitrogenous excretion rates also varied significantly throughout the season (Fig. 3). By the end of summer, ammonia excretion had already decreased to levels not significantly different (ANOVA, $\mathrm{p}<0.05, F=40.25$, $\mathrm{df}=3$ ) from winter values (Fig. $3 \mathrm{~A}$ ). At the start of the following summer, ammonia excretion rates increased, peaking in December. Minimal ammonia excretion rates in February $\left(66.23 \pm 5.72 \mathrm{nmol} \mathrm{h}^{-1}\right)$ were only $39 \%$ of maximal summer rates in December (170.83 \pm $9.50 \mathrm{nmol} \mathrm{h}^{-1}$ ). Urea excretion showed a significant (Kruskal-Wallis, $\mathrm{p}<0.05, H=13.64$, df $=3$ ) seasonal pattern with maximum excretion rates in the winter and considerably lower rates in summer (Fig. 3B). The highest rates of urea excretion occurred in July $\left(26.70 \pm 4.05 \mathrm{nmol} \mathrm{h}^{-1}\right)$ and the lowest rates in December $\left(9.88 \pm 1.60 \mathrm{nmol} \mathrm{h}^{-1}\right)$, a decrease of $63 \%$ from winter to summer. FPS excretion did not show a clear seasonal pattern, only December was significantly different (Kruskal-Wallis, $\mathrm{p}<0.05, H=24.49, \mathrm{df}=3$ ) from the other 3 sampling points (Fig. 3C).

$\mathrm{O}: \mathrm{N}$ ratios were generally low and showed a distinct seasonal variation. Ratios decreased slowly at the end of the summer from values approaching 20 to around 7 at the start of the following summer (Fig. 4). These data suggest that protein is the dominant respiratory substrate throughout the year, although in February and July, when O:N ratios are at their highest, lipids or carbohydrates may also be making a significant contribution to the respiratory substrate pool. O:N ratios in February and July were significantly different (Kruskal-Wallis, $\mathrm{p}<0.05, H=45.06, \mathrm{df}=3$ ) from October and December.

\section{Faecal egestion}

There was no significant difference in the shell lengths or body masses of limpets used to measure faecal egestion at the 4 sampling points (Table 1). Faecal egestion rates were calculated as a mean value per $12 \mathrm{~h}$ sampling point (i.e. a mean of 6 beakers contain- 

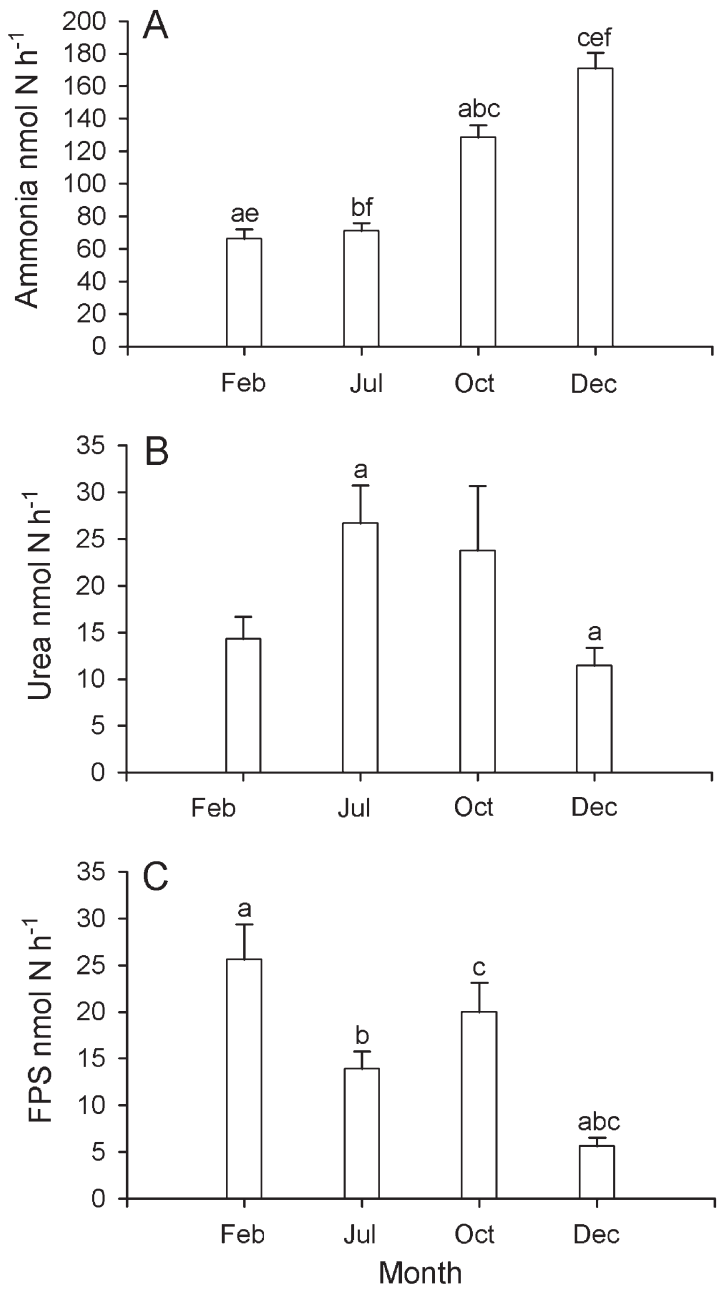

Fig. 3. Nacella concinna. Seasonal nitrogen excretion in limpet at Rothera Point, Antarctica. All data expressed as nmol N ind. $^{-1} \mathrm{~h}^{-1}$ and standardised to a limpet of tissue dry mass $247 \mathrm{mg}$ using a scaling exponent of 0.82. (A) Ammonia nitrogen, February $n=21$, July $n=20$, October $n=20$, December $\mathrm{n}=21$. (B) Urea nitrogen, February $\mathrm{n}=18$, July $\mathrm{n}=20$, October $n=14$, December $n=21$. (C) Primary amine FPS nitrogen, February $n=21$, July $n=20$, October $n=20$, December $n=21$. All bars are mean \pm SEM, bars with the same letter are significantly different to each other $(p<0.05)$. Statistical comparisons were carried out using ANOVA for ammonia data and

the Kruskal-Wallis test for urea and FPS nitrogen data

ing 10 to 30 individuals) each standardised to a limpet of $247 \mathrm{mg}$ dry mass (the mean dry body mass over the total experiment). There was no significant difference $(p>0.05)$ in the rate of faecal egestion over the first or second $24 \mathrm{~h}$ period; therefore, the results were pooled and a daily mean faecal egestion rate was calculated over the $48 \mathrm{~h}$ measurement period. There was a significant (ANOVA, $\mathrm{p}<0.05, F=28.79$, $\mathrm{df}=3$ ) seasonal pattern in faecal egestion rates, with peak summer rates in February 10 times higher than minimum rates in July (Fig. 5). The continued production of faeces in winter suggests Nacella concinna feeds continually throughout the year, although it is clear that the intensity of feeding varies strongly on a seasonal basis.

\section{DISCUSSION}

\section{Seasonal changes in AFDM}

The AFDM of Nacella concinna at Rothera Point, Antarctica, decreased by $47 \%$ during winter, suggesting that it is reliant on utilisation of body tissue to counteract the winter reduction in food consumption (Fig. 5). This compares closely with the $42 \%$ seasonal decrease in AFDM reported for the regular echinoid Sterechinus neumayeri at the same location (Brockington \& Peck 2001). Winter O:N ratios in $S$. neumayeri are higher than in N. concinna, suggesting a greater reliance on lipids for metabolism than $N$. concinna during winter (Mayzaud \& Conover 1988, Brockington \& Peck 2001). In both species, however, winter metabolic demands appear to be met by a general utilisation of body tissue rather than a specific over-wintering lipid store, such as is found in many polar zooplankton (Clarke \& Peck 1991).

\section{Oxygen consumption}

The oxygen consumption rates measured in the current work fall at the lower range of those previously measured in Nacella concinna (Table 2). The limpets in our work may have had sub-optimal feeding rates in the 24 to $48 \mathrm{~h}$ prior to respiration measurements resulting in lower metabolic rates, although limpets were observed grazing biofilms on aquarium tanks. It is also possible that higher respiration rates measured by

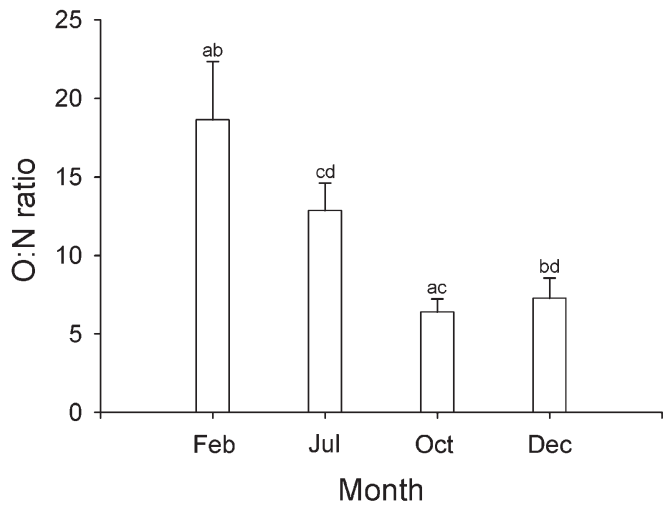

Fig. 4. Nacella concinna. Seasonal variation in O:N ratio at Rothera Point, Antarctica. All bars are mean \pm SEM, bars with the same letter are significantly different to each other (Kruskal-Wallis test, $\mathrm{p}<0.05$ ), February and December $\mathrm{n}=21$, July and October $\mathrm{n}=20$ 


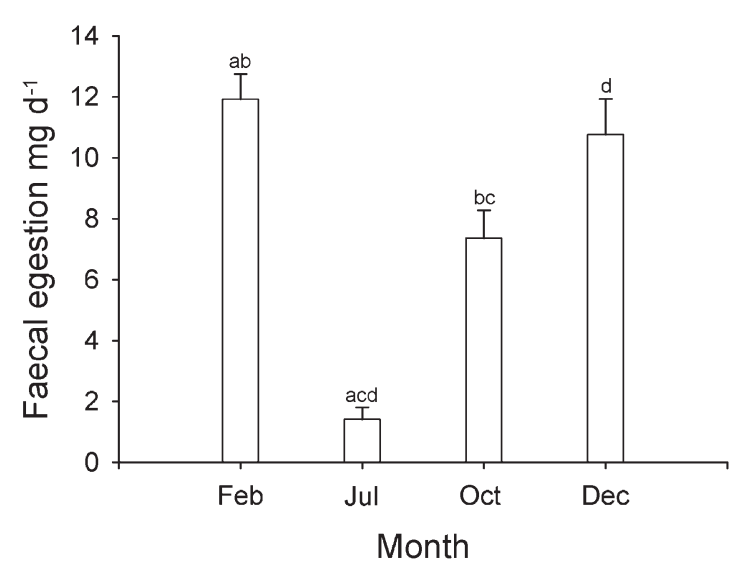

Fig. 5. Nacella concinna. Faecal egestion rates at Rothera Point, Antarctica. All data are expressed as mg faeces ind. ${ }^{-1}$ $\mathrm{d}^{-1}$. All bars are mean \pm SEM of 6 replicates, bars with the same letter are significantly different to each other (ANOVA, $\mathrm{p}<0.05)$

Peck \& Veal (2001) were a result of the starvation and feeding protocol used. Significantly higher metabolic rates were reported for N. concinna at South Georgia and Signy Island (Table 2). The lower respiration rates reported in more recent studies of $N$. concinna are probably related to the lower water temperatures and experimental protocols designed to minimise handling and experimental stress (Clarke 1983).

Seasonal oxygen consumption rates have recently been published for 3 polar marine invertebrates; the infaunal bivalve Laternula elliptica (Brockington 2001a) and the urchin Sterechinus neumayeri (Brockington \& Peck 2001) from Rothera Point, Antarctica, and an Arctic amphipod, Monoporeia affinis (Lehtonen 1996). Antarctic nearshore marine environments are characterised by marked interannual variability in ice cover, temperature, and the intensity and duration of the phytoplankton bloom (Murphy et al. 1995, Clarke \& Leakey 1996). The duration of fast-ice during our study was intermediate to the $2 \mathrm{yr}$ in which seasonal physiology was studied in L. elliptica and $S$. neumayeri (Brockington 2001a, Brockington \& Peck 2001), and the seasonal pattern of both temperature and water column chlorophyll was broadly similar (British Antarctic Survey unpubl. data). This suggests that any differences in seasonal patterns of physiology between $N$. concinna, $L$. elliptica and $S$. neumayeri are unlikely to be due to seasonal environmental variation between the studies.

The size of the maximum seasonal factorial rise in Nacella concinna oxygen consumption was $\times 1.6$, considerably smaller than that reported in Sterechinus neumayeri, $(\times 2.5$ to 3.1 : Brockington \& Peck 2001) and Laternula elliptica $(\times 3$ : Brockington 2001a), but greater than the $\times 1.2$ increase in Monoporeia affinis (Lehtonen 1996). Both $S$. neumayeri and L. elliptica cease feeding completely during the austral winter for 4 and 6 to 7 mo, respectively (Brockington \& Peck 2001, Brockington 2001a). O:N ratios suggest that $M$. affinis ceases feeding during winter, but relies on large lipid reserves to fuel metabolism (Lehtonen 1996). In contrast, $N$. concinna feeds throughout the winter at Rothera, albeit at considerably reduced rates (Fig. 5). This winter feeding will reduce the seasonal variation in metabolic rate, as has been shown for the bivalve Mytilus edulis (Hawkins et al. 1985). The metabolic costs of winter feeding results in a higher mass-specific oxygen consumption in $N$. concinna (51 and $55 \mu \mathrm{mol} \mathrm{g}^{-1} \mathrm{~d}^{-1}$ in February and October, respectively) compared with S. neumayeri (57 and 30 in March and September, respectively) and L. elliptica (80 and 32 in March and September, respectively).

\section{O:N ratios, ammonia, urea and FPS excretion}

Ammonia excretion rates have only previously been measured in Nacella concinna during the austral summer or in animals returned to the UK (Clarke 1990,

Table 2. Nacella concinna. Comparison of oxygen consumption data. All data have been converted to a standard dry tissue mass of $247 \mathrm{mg}$ using a scaling exponent of 0.82 . Units are $\mu \mathrm{mol} \mathrm{h}{ }^{-1}\left(\mathrm{O}_{2}\right.$ ind $\left.{ }^{-1}\right)$. Routine rates are those measured immediately after being sampled in the field. For the study reported here, limpets were held in aquaria prior to measurement (see 'Materials and methods'). Limpets measured in UK originated at Signy Island

\begin{tabular}{|lcccc|}
\hline Site & Status & Temperature $\left({ }^{\circ} \mathrm{C}\right)$ & Oxygen consumption & Source \\
\hline Rothera & Winter & -1.4 & 0.38 & This study \\
Rothera & Summer & 0.5 & 0.61 & This study \\
UK Lab & Starved & 0 & 0.60 & Peck (1989) \\
UK Lab & Starved & -1.5 & 0.49 & Peck (1989) \\
UK Lab & Starved & -0.65 & 0.99 & Peck \& Veal (2001) \\
UK Lab & Fed & -0.65 & 2.46 & Peck \& Veal (2001) \\
South Georgia & Routine & 5.0 & 2.48 & Ralph \& Maxwell (1977) \\
Signy Island & Routine & -1.5 & 3.09 & Houlihan \& Allan (1982) \\
Signy Island & Routine & 0.5 & 3.55 & Houlihan \& Allan (1982) \\
\hline
\end{tabular}


Clarke et al. 1994, Peck \& Veal 2001). Clarke (1990) and Clarke et al. (1994) reported ammonia excretion rates (corrected to a standard dry mass of $247 \mathrm{mg}$ ) in fed $N$. concinna of $114 \mu \mathrm{mol} \mathrm{h}{ }^{-1}\left(1.3^{\circ} \mathrm{C}\right)$ and $122 \mu \mathrm{mol}$ $\mathrm{h}^{-1}\left(-0.25^{\circ} \mathrm{C}\right)$, respectively, values consistent with those measured during summer in the current work. Peck \& Veal (2001) have shown that under conditions of short-term food deprivation, $N$. concinna increased its rate of ammonia excretion to $541 \mu \mathrm{mol} \mathrm{h}^{-1}$, while on re-feeding, rates decreased to $135 \mu \mathrm{mol} \mathrm{h}{ }^{-1}$, suggesting that protein catabolism plays a major role in fuelling metabolism during acute nutritional stress. In contrast, under conditions of natural (seasonal) reduced food availability during the Antarctic winter (July), ammonia excretion rates remain low (Fig. 3A).

In spring (December), feeding and ammonia excretion rates are high, whereas O:N ratios are low. This suggests that in early spring ingested lipids may be used preferentially for gonad maturation rather than to provide energy. Nacella concinna usually spawns during the spring bloom period (Powell et al. 2001). Reduced protein catabolism in February, when feeding rates are maximal, maybe an attempt to 'retain' protein for growth before the onset of winter. As feeding and metabolic rates decrease in winter, supplies of lipids and carbohydrates are still available to offset some protein catabolism as $\mathrm{O}: \mathrm{N}$ ratios suggest not all metabolic fuel is protein-derived (Figs. 2, 3, 4 \& 5, July). The difference between the effects of acute starvation (Peck \& Veal 2001) and seasonal ration restriction (Fig. 4) on nitrogen metabolism in $N$. concinna is significant in underlining the importance of relating physiological measurements to the ecological and seasonal history of the animal under study. Bayne \& Scullard (1977) have also shown seasonal differences in the effects of starvation on ammonia excretion in Mytilus edulis; if the mussels were starved in winter, ammonia excretion rates increased; while if they were starved in summer or autumn, ammonia excretion rates decreased.

This study represents the first comprehensive seasonal nitrogen excretion data, incorporating ammonia, urea and FPS measures for an Antarctic invertebrate, although seasonal ammonia excretion data have recently been published for 2 other Antarctic invertebrates. In both Laternula elliptica (Brockington \& Peck 2001) and Sterechinus neumayeri (Brockington 2001a), the factorial difference between summer and winter ammonia excretion minima and maxima was considerably greater than in Nacella concinna (Fig. 3A). This confirms the conclusions from the oxygen consumption data that the small amount of feeding during winter and stored energy reserves from summer considerably reduce the degree of metabolic seasonality exhibited by $N$. concinna in comparison to L. elliptica and $S$. neumayeri.
Relatively few authors report on simultaneous measures of different forms of excreted nitrogen. Clarke et al. (1994) reported urea excretion rates of $10.32 \mu \mathrm{mol} \mathrm{h}^{-1}$ and FPS excretion rates of $3.9 \mu \mathrm{mol} \mathrm{h}^{-1}$ in December in fed Nacella concinna at a water temperature of $-0.25^{\circ} \mathrm{C}$, values very similar to those measured in the current work in December. However, it is clear from Fig. 3 that significant seasonal changes occur in the rates of both urea and FPS excretion through the year. If the sum of ammonia, urea and FPS excretion are assumed to comprise the total nitrogen excretion, then the relative proportions of each nitrogenous excretory product can be assessed seasonally. Although it is likely that these 3 excretory products comprise the vast majority of nitrogenous excretion, other substances such as uric acid may also be excreted in small amounts (Carefoot 1987) and have not been measured in this study. Clarke et al. (1994) found that in December, urea and FPS comprised 7.9 and $3.3 \%$ of total nitrogenous excretion in $N$. concinna, respectively, which is similar to data presented here (Table 3). However, it is clear that there are large seasonal variations in the proportions of urea and FPS excreted in $N$. concinna with values varying as high as 24.5 and $24.3 \%$, respectively (Table 2). Nicol (1967) collated data for primary amine and purine excretion in molluscs (both of which will be measured as FPS in the current work) and urea, and showed that in a range of species, FPS can account for 13 to $51 \%$ and urea from trace amounts to $15 \%$ of nitrogen excretion. The higher rates of urea excretion in $N$. concinna are probably due to elevated tissue concentrations of RNA (Fraser et al. 2002).

Although ammonia is always the dominant nitrogenous excretory product in Nacella concinna, at some times of the year urea and FPS can together account for up to $38 \%$ of excreted nitrogen. More seasonal data are certainly required before firm conclusions can be drawn on nitrogen excretion in marine invertebrates, some reported intra-specific differences may in fact be due to the time of year the measurements were made (reviewed in Nicol 1967).

Current evidence suggests that the ornithine cycle is not present in molluscs (Nicol 1967); excreted urea must therefore be derived from deamination of arginine by arginase and/or the breakdown of pyrimidines and purines from endogenous or exogenous sources (Prosser \& Brown 1962, Clarke et al. 1994). The increase in urea excretion during the winter (Fig. 3B) may well be related to a seasonal decrease in tissue RNA concentrations allied to a decrease in protein synthesis rates (Fraser et al. 2002). RNA breakdown will result in the release of purines and pyrimidines (Prosser \& Brown 1962), although at present very little is known regarding the excretory products and pathways of nucleic acid metabolism in Nacella concinna (Clarke et al. 
Table 3. Nacella concinna. Percentage contribution by ammonia, urea and fluorescamine-positive substances to overall nitrogen excretion

\begin{tabular}{|c|c|c|c|c|}
\hline & Feb & Jul & Oct & Dec \\
\hline Ammonia & $64.3 \pm 4.1$ & $62.6 \pm 3.3$ & $79.3 \pm 2.9$ & $90.7 \pm 1.1$ \\
\hline Urea & $24.5 \pm 3.3$ & $13.1 \pm 1.8$ & $11.7 \pm 1.6$ & $3.3 \pm 0.6$ \\
\hline Fluorescamine-positive substances & $13.1 \pm 2.0$ & $24.3 \pm 2.9$ & $12.8 \pm 2.5$ & $6.5 \pm 1.1$ \\
\hline
\end{tabular}

1994) or any other cold-water invertebrate. The pattern of FPS excretion in N. concinna is difficult to explain; certainly no clear seasonal pattern exists (Fig. 3C), although when expressed as a proportion of nitrogen excretion, a seasonal pattern is evident (Table 3 ).

\section{Faecal egestion}

Clarke (1990) concluded that Nacella concinna faecal egestion rates in summer at Signy Island were comparable to published data on a range of grazing marine molluscs. Rates measured at Rothera Point in the current work during December of $10 \mathrm{mg} \mathrm{d}^{-1}$ are about $1 / 2$ of those reported by Clarke (1990) and clearly show that although feeding is very seasonal, some food consumption occurs year round. The reason for the large difference in faecal egestion rates between the 2 studies is unclear, but may be the result of a decrease in food availability at higher latitudes. At Signy Island $\left(60^{\circ} 43^{\prime} \mathrm{S}\right)$, maximum chl a concentrations in surface sediments reached $300 \mathrm{mg} \mathrm{m}^{-2}$ in summer, decreasing to about $20 \mathrm{mg} \mathrm{m}^{-2}$ in winter (Gilbert 1991). While at

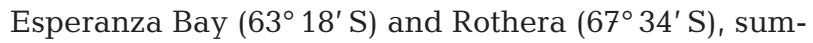
mer chl a concentrations only reach 17 and $90 \mathrm{mg} \mathrm{m}^{-2}$, respectively, and decreased to 2 and $5 \mathrm{mg} \mathrm{m}^{-2}$, respectively, in winter (Brêthes et al. 1994, Brockington 2001b). Although physical differences exist between these sites, a latitudinal gradient in benthic productivity seems likely, probably driven by latitudinal differences in seasonal light availability. Dietary analysis by Shabica (1976) showed that diatoms and filamentous algae dominate the diet of $N$. concinna. Brêthes et al. (1994) also demonstrated that microphytobenthos is probably the major food source of $N$. concinna, with ice algae and phytoplankton not being that important as food sources. The seasonal variation in food consumption in $N$. concinna is therefore likely to be driven by food availability.

A recent laboratory study has suggested that in Sterechinus neumayeri from the same study site as the current work, 80 to $85 \%$ of the summer increase in metabolism is caused by increased physiological activity associated with feeding, growth and spawning, whereas only 15 to $20 \%$ is associated with the direct effects of summer increases in water temperature (Brockington \& Clarke 2001). While Nacella concinna feeds throughout the year, $S$. neumayeri ceases feeding for 4 to $7 \mathrm{mo}$; the former species shows a comparatively small seasonal variation in metabolism, while the latter species shows a much larger seasonal variation (Brockington \& Peck 2001). This provides circumstantial evidence that food consumption rather than water temperature is probably driving seasonal changes in metabolic rate in these Antarctic species.

Acknowledgements. The authors are grateful to the Rothera Field Diving Officers Steve Dunkerley and Craig Barnes and the Marine Assistant Jenny Beaumont for diving support. Boating assistance was provided by Martin Warnock and Ian McDonald. Dr. David Barnes provided useful comments on the manuscript. The work was carried out as part of the British Antarctic Survey Marine Organismal Adaptations project, part of the Life at the Edge: Stresses and Thresholds programme. In addition, the work also forms a contribution to the EASIZ (Ecology of the Antarctic Sea-Ice Zone) programme of SCAR (Scientific Committee on Antarctic Research).

\section{LITERATURE CITED}

Barnes DKA, Clarke A (1994) Seasonal variation in the feeding activity of four species of Antarctic bryozoan in relation to environmental factors. J Exp Mar Biol Ecol 181: $117-133$

Bayne BL, Scullard C (1977) Rates of nitrogen excretion by species of Mytilus (Bivalvia: Mollusca). J Mar Biol Assoc UK 57:355-369

Berry RJ, Rudge PJ (1973) Natural selection in Antarctic limpets. Br Antarct Surv Bull 35:73-81

Brêthes JC, Ferreyra G, De la Vega S (1994) Distribution, growth and reproduction of the limpet Nacella (Patinigera) concinna (Strebel 1908) in relation to potential food availability, in Esperanza Bay (Antarctic Peninsula). Polar Biol 14:161-170

Brockington S (2001a) The seasonal energetics of the Antarctic bivalve Laternula elliptica (King and Broderip) at Rothera Point, Adelaide island. Polar Biol 24:523-530

Brockington S (2001b) Ecology and physiology of $S$. neumayeri at Adelaide Island, Antarctica. PhD thesis, Open University, UK

Brockington S, Clarke A (2001) The relative influence of temperature and food on the metabolism of a marine invertebrate. J Exp Mar Biol Ecol 258:87-99 
Brockington S, Peck LS (2001) Seasonality of respiration and ammonium excretion in the Antarctic echinoid Sterechinus neumayeri. Mar Ecol Prog Ser 219:159-168

Cadée GC (1999) Shell damage and shell repair in the Antarctic limpet Nacella concinna from King George Island. J Sea Res 41:149-161

Carefoot TH (1987) Gastropoda. In: Pandian TJ, Vernberg FJ (eds) Animal energetics, Vol 2. Bivalvia through reptilia. Academic Press, London, p 89-172

Catalano G (1987) An improved method for the determination of ammonia in seawater. Mar Chem 20:289-295

Clarke A (1983) Life in cold water: the physiological ecology of polar marine ectotherms. Oceanogr Mar Biol Annu Rev 21:341-453

Clarke A (1988) Seasonality in the Antarctic marine environment. Comp Biochem Physiol 90B(3):461-473

Clarke A (1990) Faecal egestion and ammonia excretion in the Antarctic limpet Nacella concinna (Strebel, 1908). J Exp Mar Biol Ecol 138:227-246

Clarke A, Leakey RJG (1996) The seasonal cycle of phytoplankton, macronutrients, and the microbial community in a nearshore Antarctic marine ecosystem. Limnol Oceanogr 41(6):1281-1294

Clarke A, Peck LS (1991) The physiology of polar marine zooplankton. Polar Res 10(2):355-369

Clarke A, Holmes LJ, White MG (1988) The annual cycle of temperature, chlorophyll and major nutrients at Signy Island, South Orkney Islands, 1969-82. Br Antarct Surv Bull 80:65-86

Clarke A, Prothero-Thomas E, Whitehouse MJ (1994) Nitrogen excretion in the Antarctic limpet Nacella concinna (Strebel, 1908). J Molluscan Stud 60:141-147

Clements LEJ, Hilbish TJ (1991) Comparison of fluorescamine and $o$-phthaldialdehyde methods for measuring amino acid exchange in marine organisms. Limnol Oceanogr 36(7):1463-1471

Degobbis D (1973) On the storage of seawater samples for ammonia determination. Limnol Oceanogr 18:146-150

Fraser KPP, Clarke A, Peck LS (2002) Low-temperature protein metabolism: seasonal changes in protein synthesis and RNA dynamics in the Antarctic limpet Nacella concinna. J Exp Biol 205:3077-3086

Gilbert NS (1991) Microphytobenthic seasonality in nearshore marine sediments at Signy Island, South Orkney Islands, Antarctica. Estuar Coast Shelf Sci 33:89-104

Hawkins AJS, Salkeld PN, Bayne BL, Gnaiger E, Lowe DM (1985) Feeding and resource allocation in the mussel Mytilus edulis: evidence for time-averaged optimization. Mar Ecol Prog Ser 20:273-287

Houlihan DF, Allan D (1982) Oxygen consumption of some Antarctic and British gastropods: an evaluation of cold adaptation. Comp Biochem Physiol 73A(3):383-387

Lehtonen KK (1996) Ecophysiology of the benthic amphipod Monoporeia affinis in an open-sea area of the northern Baltic Sea: seasonal variations in oxygen consumption and ammonia excretion. Mar Biol 126:645-654

Liddicoat MI, Tibbitts S, Butler EI (1975) The determination of ammonia in seawater. Limnol Oceanogr 20:131-132

Littlepage JL (1965) Oceanographic investigations in McMurdo Sound, Antarctic. In: Llano GA (ed) Biology of the Antarctic seas, Vol II. Antarctic Research Series 5. American Geophysical Union, Washington, DC, p 1-37

Editorial responsibility: Otto Kinne (Editor),

Oldendorf/Luhe, Germany
Mayzaud P, Conover RJ (1988) O:N atomic ratio as a tool to describe zooplankton metabolism. Mar Ecol Prog Ser 45: 289-302

Murphy EJ, Clarke A, Syman C, Priddle J (1995) Temporal variation in Antarctic sea-ice: analysis of a long-term fastice record from the South Orkney Islands. Deep-Sea Res 42:1045-1062

Nicol JAC (1967) The biology of marine animals, 2nd edn. Wiley-Liss, New York

North BB (1975) Primary amines in California coastal waters: utilization by phytoplankton. Limnol Oceanogr 20(1): $20-27$

Peck LS, Uglow RF (1990) Two methods for the assessment of the oxygen content of small volumes of seawater. J Exp Mar Biol Ecol 141:53-62

Peck LS, Veal R (2001) Feeding, metabolism and growth in the Antarctic limpet, Nacella concinna (Strebel 1908). Mar Biol 138:553-560

Peck LS, Whitehouse MJ (1992) An improved desorber design for use in couloximetry. J Exp Mar Biol Ecol 163:163-167

Peck LS, Prothero-Thomas E, Hough N (1993) Pedal mucus production by the Antarctic limpet Nacella concinna (Strebel, 1908). J Exp Mar Biol Ecol 174:177-192

Picken GB (1980) The distribution, growth, and reproduction of the Antarctic limpet Nacella (Patinigera) concinna (Strebel, 1908). J Exp Mar Biol Ecol 42:71-85

Picken GB, Allan D (1983) Unique spawning behavior by the Antarctic limpet Nacella concinna (Strebel 1908). J Exp Mar Biol Ecol 71:283-287

Powell DK, Tyler PA, Peck LS (2001) Effect of sperm concentration and sperm aging on fertilization success in the Antarctic soft-shelled clam Laternula elliptica and the Antarctic limpet Nacella concinna. Mar Ecol Prog Ser 215: 191-200

Price NM, Harrison PJ (1987) Comparison of methods for the analysis of dissolved urea in seawater. Mar Biol 94: $307-317$

Prosser CL, Brown FA (1962) Comparative animal physiology, 2nd edn. Saunders, Philadelphia

Rahmatullah M, Boyde TRC (1980) Improvements in the determination of urea using diacetyl monoxime; methods with and without deproteinisation. Clinica Chim Acta 107:3-9

Ralph R, Maxwell JGH (1977) The oxygen consumption of the Antarctic limpet Nacella (Patinigera) concinna. Br Antarct Surv Bull 45:19-23

Shabica SV (1976) The natural history of the Antarctic limpet Patinigera polaris (Hombron and Jacquinot). PhD thesis, Oregon State University, Corvallis, OR

Sokal RR, Rohlf FJ (1995) Biometry, 3rd edn. WH Freeman, New York

Solorzano L (1969) Determination of ammonia in natural waters by the phenylhypochlorite method. Limnol Oceanogr 14:799-801

Stanwell-Smith D, Clarke A (1998) The timing of reproduction in the Antarctic limpet Nacella concinna (Strebel, 1908) (Patellidae) at Signy Island, in relation to environmental variables. J Molluscan Stud 64:123-127

Walker AJM (1972) Introduction to the ecology of the Antarctic limpet Patinigera polaris (Hombron and Jacquinot) at Signy Island, South Orkney Islands. Br Antarct Surv Bull 28:49-69

Submitted: December 3, 2001; Accepted: May 31, 2002

Proofs received from author(s): September 12, 2002 